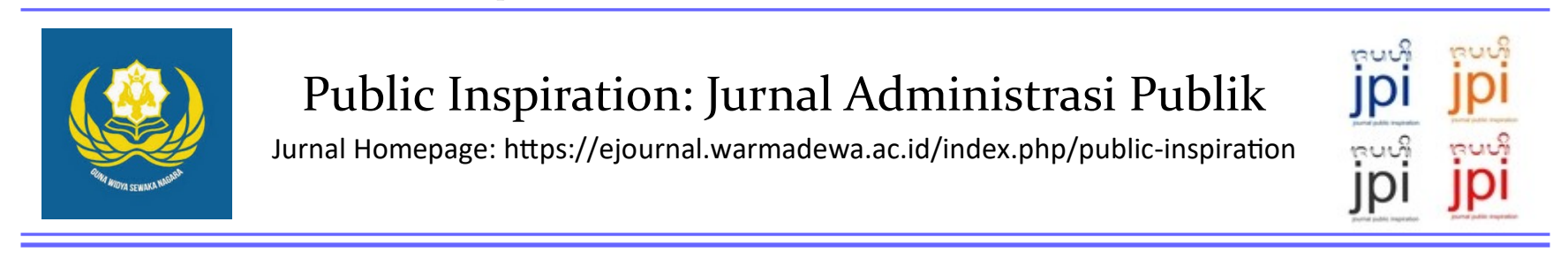

\title{
Aksesibilitas Penyandang Disabilitas dalam Pemilu 2019 di Kabupaten Sleman
}

\author{
Dwi Astuti dan Didik G. Suharto* \\ Universitas Sebelas Maret, Surakarta, Jawa Tengah-Indonesia \\ Email Corespondence: didikgsuharto@staff.uns.ac.id
}

How to Cite: Astuti, D., \& Suharto, D. G. (2021). Aksesibilitas Penyandang Disabilitas dalam Pemilu 2019 di Kabupaten Sleman. Public Inspiration: Jurnal Administrasi Publik, 6(1). 29-41. DOI: https://doi.org/10.22225/pi.6.1.2021.29-41

\begin{abstract}
This research aims to analyze the accessibility of persons with disabilities in the 2019 general election in Sleman Regency, Daerah Istimewa Yogyakarta (DIY) Province. This research was assessed using the dimensions according to Thomas and Penchansky, which consist of the dimensions of accessibility, accommodation, availability, and acceptability. This research is a qualitative descriptive study using interview and documentation techniques to collect data. Existing data were analyzed using an interactive model analysis technique from Miles and Huberman. The results showed that the 2019 general election in Sleman Regency was not yet accessible for people with disabilities. Based on the accessibility dimension, there is a fact that the polling stations (TPS) provided by the organizers are not yet fully accessible to persons with disabilities, such as the presence of stairs that make it difficult for persons with disabilities to enter the TPS. In the accommodation dimension, there are still TPS officer services that are not friendly to persons with disabilities. Based on the availability dimension, there are constraints on the availability of materials, machines, and methods so that they are not optimal in accommodating the rights of voters with disabilities. In the acceptability dimension, it is not yet friendly for people with disabilities, because there are still inaccurate perceptions from some people towards people with disabilities. Election organizers are advised to pay more attention to access for persons with disabilities, particularly regarding the affordability of polling stations, the availability of facilities and infrastructure, the availability of standard operating procedures (SOPs) for persons with disabilities, the skills and alertness of officers in dealing with voters with disabilities, as well as improving the public's perspective in viewing persons with disabilities.
\end{abstract}

Keywords: Accessibility; Disability; General election

\begin{abstract}
Abstrak
Penelitian ini bertujuan untuk menganalisis aksesibilitas penyandang disabilitas dalam Pemilihan Umum 2019 di Kabupaten Sleman, Provinsi Daerah Istimewa Yogyakarta (DIY). Penelitian ini dikaji dengan menggunakan dimensi menurut Thomas dan Penchansky, yang terdiri dari dimensi aksesibilitas, akomodasi, ketersediaan, dan akseptabilitas. Penelitian ini merupakan penelitian deskriptif kualitatif dengan menggunakan tehnik wawancara dan dokumentasi untuk mengumpulkan data. Data yang ada dianalisis menggunakan tehnik analisis model interaktif dari Miles dan Huberman. Hasil penelitian menunjukkan bahwa Pemilihan Umum 2019 di Kabupaten Sleman belum aksesibel bagi penyandang disabilitas. Berdasar dimensi aksesibilitas, terdapat fakta bahwa Tempat Pemungutan Suara (TPS) yang disediakan oleh penyelenggara belum seluruhnya mudah diakses oleh penyandang disabilitas, seperti adanya tangga yang menyulitkan penyandang disabilitas untuk masuk ke TPS. Pada dimensi akomodasi, masih ada pelayanan petugas TPS yang belum ramah terhadap penyandang disabilitas. Berdasar dimensi ketersediaan, terdapat kendala ketersediaan material, machine, dan method sehingga tidak optimal dalam mengakomodasi hak-hak pemilih penyandang disabilitas. Pada dimensi akseptabilitas belum ramah bagi penyandang disabilitas, karena masih adanya persepsi yang kurang tepat dari sebagian masyarakat terhadap penyandang disabilitas. Penyelenggara Pemilihan Umum disarankan untuk lebih memperhatikan akses bagi penyandang disabilitas, khususnya mengenai keterjangkauan TPS, ketersediaan sarana dan prasarana,
\end{abstract}


ketersediaan standar operasional prosedur (SOP) bagi penyandang disabilitas, keterampilan dan kesigapan petugas dalam menangani pemilih penyandang disabilitas, serta memperbaiki cara pandang masyarakat dalam memandang penyandang disabilitas.

Kata kunci: Akesibilitas; Disabilitas; Pemilihan umum

\section{Pendahuluan}

Indonesia merupakan salah satu negara yang menerapkan prinsip demokrasi dalam sistem pemerintahannya, dimana memberikan kesempatan bagi rakyat untuk berpartisipasi dalam proses politik dan pemerintahan, tidak terkecuali dalam menentukan kebijakan dan memilih pemimpin. Salah satu bentuk perwujudan dari prinsip demokrasi adalah diselenggarakannya Pemilu dalam rangka menyerap aspirasi masyarakat untuk memilih pemimpin negara. Salah satu hal terpenting dalam penyelenggaraan Pemilu atau Pilkada adalah partisipasi warga yang telah memenuhi syarat dalam menggunakan hak pilih politiknya termasuk penyandang disabilitas. Menurut data TNP2K 2012 dalam (Salim, 2015) jumlah difabel di Indonesia mencapai angka 10\% atau sekitar 25 juta jiwa dari jumlah keseluruhan penduduk Indonesia yaitu sebanyak 250 juta jiwa.

Dalam UU Nomor 19 Tahun 2011 tentang Pengesahan Convention On The Rights of Person of Disabilities, terdapat pernyataan bahwa Indonesia memiliki kewajiban dalam merealisasikan hak-hak penyandang disabilitas di segala bidang kehidupan termasuk kehidupan berpolitik, untuk menghindari tindakan diskriminatif. Salah satu hak politik yang harus didapatkan oleh penyandang disabilitas adalah hak untuk memberikan suara dalam Pemilu maupun Pilkada.

Pada tanggal 17 April 2019, pemerintah Indonesia secara serentak menggelar pemilihan umum Presiden dan Wakil Presiden RI, serta pemilihan anggota DPR, DPD, DPRD Provinsi, dan DPRD Kabupaten/Kota. Pemilihan umum Presiden / Wakil Presiden dan anggota legislatif diselenggarakan serentak di seluruh Indonesia termasuk Provinsi Daerah Istimewa Yogyakarta (DIY). Di wilayah Daerah Istimewa Yogyakarta berdasar data KPU terdapat daftar pemilih tetap sebanyak 2.731.874 pemilih pada Pemilu 2019, dengan 11.370 pemilih diantaranya adalah pemilih disabilitas. Tabel 1 memperlihatkan jumlah pemilih di kabupaten/kota Daerah Istimewa Yogyakarta.

Tabel 1

Rekapitulasi Daftar Pemilih Pemilu 2019 Daerah Istimewa Yogyakarta

\begin{tabular}{cccccccc}
\hline No & $\begin{array}{c}\text { Kabupaten/ } \\
\text { Kota }\end{array}$ & Kec. & Kel. & TPS & Laki-laki & Perempuan & $\begin{array}{c}\text { Total } \\
\text { Pemilih }\end{array}$ \\
\hline 1 & Kulon Progo & 12 & 88 & 1.258 & 162.843 & 172.050 & 334.893 \\
2 & Bantul & 17 & 75 & 3.040 & 346.485 & 360.524 & 707.009 \\
3 & Gunungkidul & 18 & 144 & 2.718 & 295.263 & 310.631 & 605.894 \\
4 & Sleman & 17 & 86 & 3.391 & 377.286 & 397.323 & 774.609 \\
5 & Kota Yogyakarta & 14 & 45 & 1.373 & 148.233 & 161.236 & 309.469 \\
& Jumlah & 78 & 438 & 11.780 & 1.330 .110 & 1.401 .764 & 2.731 .874 \\
\hline
\end{tabular}

Sumber: Data Pemilih Tetap Pemilu 2019 (https://data.kpu.go.id/)

Sementara itu, menurut data dari Dinas Sosial Pemerintah Provinsi Daerah Istimewa Yogyakarta terdapat 25.050 orang penyandang disabilitas. Berdasar jenis kelamin, penyandang disabilitas laki-laki sebanyak 13.589 orang dan perempuan dengan disabilitas sebanyak 11.461 orang. Dari jumlah penyandang disabilitas yang tersebar di berbagai kabupaten maupun kota di DIY, diketahui bahwa jumlah penyandang disabilitas di wilayah Kabupaten Sleman sebanyak 5.535 orang, dimana dari jumlah tersebut terdapat 2.922 orang penyandang disabilitas yang terdaftar dalam daftar pemilih tetap (DPT) di KPU Kabupaten Sleman. Persebaran pemilih disabilitas di setiap kecamatan di Kabupaten 
Sleman sebagaimana dalam Tabel 2.

Jumlah disabilitas di wilayah Kabupaten Sleman yang besar, menuntut pemerintah (khususnya penyelenggara Pemilu atau Komisi Pemilihan Umum/KPU) untuk proaktif memfasilitasi kelompok disabilitas agar hak sebagai warga negara terpenuhi. Rendahnya partisipasi penyandang disabilitas untuk memilih atau dipilih dalam proses politik bisa mengurangi legitimasi Pemilu, bahkan turunnya kepercayaan (public trust) terhadap pemerintah. Hal ini akan berimplikasi pada ketahanan politik, karena tanpa kepercayaan publik maka kunci penting dalam membangun masyarakat yang demokratis tidak akan terwujud.

\section{Tabel 2}

Sebaran Pemilih Disabilitas KPU Kabupaten Sleman

\begin{tabular}{|c|c|c|c|c|c|c|c|c|c|c|c|}
\hline \multirow[t]{2}{*}{ No } & \multirow[t]{2}{*}{ Kecamatan } & \multicolumn{2}{|c|}{$\begin{array}{l}\text { Tuna } \\
\text { Daksa }\end{array}$} & \multicolumn{2}{|c|}{$\begin{array}{l}\text { Tuna } \\
\text { Netra }\end{array}$} & \multicolumn{2}{|c|}{$\begin{array}{c}\text { Tuna } \\
\text { Rungu }\end{array}$} & \multicolumn{2}{|c|}{$\begin{array}{c}\text { Tuna } \\
\text { Grahita }\end{array}$} & \multicolumn{2}{|c|}{$\begin{array}{c}\text { Disabilitas } \\
\text { Lainnya }\end{array}$} \\
\hline & & $\mathrm{L}$ & $\mathrm{P}$ & $\mathrm{L}$ & $\mathrm{P}$ & $\mathrm{L}$ & $\mathrm{P}$ & $\mathrm{L}$ & $\mathrm{P}$ & $\mathrm{L}$ & $\mathrm{P}$ \\
\hline 1 & Berbah & 9 & 6 & 10 & 10 & 14 & 5 & 9 & 6 & 15 & 21 \\
\hline 2 & Cangkringan & 17 & 15 & 5 & 2 & 12 & 10 & 15 & 8 & 18 & 11 \\
\hline 3 & Depok & 18 & 9 & 7 & 8 & 7 & 7 & 10 & 6 & 7 & 11 \\
\hline 4 & Gamping & 15 & 18 & 20 & 16 & 16 & 11 & 27 & 17 & 18 & 24 \\
\hline 5 & Godean & 25 & 12 & 19 & 12 & 11 & 10 & 21 & 16 & 14 & 17 \\
\hline 6 & Kalasan & 35 & 31 & 22 & 29 & 17 & 21 & 44 & 33 & 21 & 23 \\
\hline 7 & Minggir & 28 & 25 & 13 & 9 & 19 & 18 & 10 & 13 & 11 & 14 \\
\hline 8 & Mlati & 21 & 26 & 13 & 7 & 13 & 15 & 16 & 14 & 29 & 15 \\
\hline 9 & Moyudan & 20 & 37 & 23 & 24 & 14 & 14 & 25 & 11 & 20 & 19 \\
\hline 10 & Ngaglik & 20 & 20 & 4 & 8 & 25 & 13 & 16 & 17 & 19 & 21 \\
\hline 11 & Ngemplak & 30 & 27 & 12 & 8 & 25 & 23 & 34 & 27 & 19 & 18 \\
\hline 12 & Pakem & 22 & 33 & 6 & 3 & 8 & 8 & 9 & 8 & 18 & 16 \\
\hline 13 & Prambanan & 15 & 17 & 17 & 16 & 13 & 9 & 14 & 16 & 44 & 29 \\
\hline 14 & Seyegan & 8 & 9 & 9 & 10 & 8 & 10 & 21 & 17 & 10 & 12 \\
\hline 15 & Sleman & 15 & 6 & 6 & 7 & 10 & 9 & 23 & 13 & 11 & 14 \\
\hline 16 & Tempel & 32 & 19 & 19 & 13 & 25 & 25 & 35 & 29 & 20 & 14 \\
\hline 17 & Turi & 40 & 7 & 7 & 8 & 29 & 32 & 69 & 65 & 23 & 17 \\
\hline & Jumlah & 370 & 317 & 212 & 190 & 266 & 240 & 398 & 316 & 317 & 296 \\
\hline & Total & \multicolumn{2}{|c|}{687} & \multicolumn{2}{|c|}{402} & \multicolumn{2}{|c|}{506} & \multicolumn{2}{|c|}{714} & \multicolumn{2}{|c|}{613} \\
\hline \multicolumn{2}{|c|}{ Total Keseluruhan } & & & & & \multicolumn{2}{|c|}{2.922} & & & & \\
\hline
\end{tabular}

Sumber: Data Pemilih Tetap Pemilu 2019 (https://data.kpu.go.id/)

Jumlah disabilitas di wilayah Kabupaten Sleman yang besar, menuntut pemerintah (khususnya penyelenggara Pemilu atau Komisi Pemilihan Umum/KPU) untuk proaktif memfasilitasi kelompok disabilitas agar hak sebagai warga negara terpenuhi. Rendahnya partisipasi penyandang disabilitas untuk memilih atau dipilih dalam proses politik bisa mengurangi legitimasi Pemilu, bahkan turunnya kepercayaan (public trust) terhadap pemerintah. Hal ini akan berimplikasi pada ketahanan politik, 
Public Inspiration: Jurnal Administrasi Publik, 6 (1) (2021), 32

Aksesibilitas Penyandang Disabilitas dalam Pemilu 2019 di Kabupaten Sleman

karena tanpa kepercayaan publik maka kunci penting dalam membangun masyarakat yang demokratis tidak akan terwujud.

Di Kabupaten Sleman, hak berpolitik penyandang disabilitas tercantum dalam Peraturan Daerah Nomor 1 Tahun 2018 tentang Penyandang Disabilitas, salah satunya hak dalam pelaksanaan pemilu. Namun pada praktiknya dalam Pemilu 17 April 2019 justru para penyandang disabilitas mengalami tindak diskriminasi dalam usahanya memberikan aspirasi. Sejumlah fenomena yang sempat muncul ialah ditemukannya sekelompok difabel yang kesulitan dalam mobilitas ke TPS, terdapat sejumlah TPS tidak ramah difabel karena berundak-undak atau memiliki anak tangga yang menyulitkan pengguna kursi roda, serta alat bantu coblos bagi disabilitas netra tidak tersedia untuk semua surat suara, sehingga KPPS hanya memberikan dua surat suara untuk disabilitas netra, yaitu surat suara Presiden/Wakil presiden dan Dewan Perwakilan Daerah (DPD).

Dari adanya fenomena tersebut, tak bisa dipungkiri bahwa saat ini kaum penyandang disabilitas masih menghadapi sejumlah hambatan untuk menggunakan hak pilihnya dalam Pemilu. Padahal Kabupaten Sleman telah memiliki payung hukum yang jelas untuk memenuhi hak-hak masyarakat penyandang disabilitas yakni Peraturan Daerah Kabupaten Sleman Nomor 1 Tahun 2018 tentang Penyelenggaraan Pelindungan dan Pemenuhan Hak-hak Penyandang Disabilitas. Dimana dalam regulasi tersebut terdapat prinsip-prinsip diantaranya kesetaraan kesempatan, non-diskriminasi, aksesibilitas serta artisipasi dan keterlibatan penuh dan efektif dalam masyarakat. Prinsip-prinsip tersebut sangat berkaitan dengan hak-hak yang harus dipenuhi bagi penyandang disabilitas dalam penyelenggaraan Pemilu. Meskipun sudah memiliki peraturan daerah, fakta di lapangan menunjukkan belum optimalnya perhatian terhadap penyandang disabilitas dalam Pemilu. Penelitian ini bertujuan untuk menganalisis aksesibilitas penyandang disabilitas dalam Pemilu 2019 di Kabupaten Sleman.

\section{Konsep}

\section{Disabilitas dan Pemilu}

Menurut John C. Maxwell, penyandang disabilitas adalah seseorang yang memiliki kelainan yang dapat mengganggu aktivitas. Impairment, menurut WHO (Kurniawan \& Forestyana, 2017), adalah keadaan hilangnya atau ketidaknormalan psikologi, fisiologi atau struktur, dan fungsi anatomi yang bersifat sementara atau permanen. Sedangkan Disability diartikan sebagai segala hambatan atau kurang mampunya seseorang melakukan sebuah aktivitas dalam batas yang dipahami normal oleh kebanyakan orang. Hambatan ini bersifat sementara atau permanen. Kurniawan (2017) menyebutkan beberapa kelompok disabilitas diantaranya pengguna kursi roda, ambulant disabled, ketulian dan gangguan pendengaran, keterbatasan visual, keterbelakangan mental, orang dengan keterbatasan kemampuan kognitif, orang dengan beragam keterbatasan kemampuan, lanjut usia, dan anak-anak.

Secara konseptual, Ibnu Tricahyono dalam (Labolo \& Ilham, 2015) mendefinisikan bahwa pemilihan umum merupakan instrumen untuk mewujudkan kedaulatan rakyat yang bermaksud membentuk pemerintahan yang absah serta sarana mengartikulasikan aspirasi dan kepentingan rakyat. Sedangkan dalam Peraturan Komisi Pemilihan Umum Nomor 9 Tahun 2019 menyebutkan bahwa Pemilihan Umum adalah sarana pelaksanaan kedaulatan rakyat untuk memilih anggota Dewan Perwakilan Rakyat, anggota Dewan Perwakilan Daerah, Presiden dan Wakil Presiden, dan untuk memilih anggota Dewan Perwakilan Rakyat Daerah, yang dilaksanakan secara langsung, umum, bebas, rahasia, jujur, dan adil dalam Negara Kesatuan Republik Indonesia berdasarkan Pancasila dan Undang-Undang Dasar Negara Republik Indonesia Tahun 1945. Adapun fungsi-fungsi dari pemilihan umum menurut Rose dan Mossawir (Labolo \& Ilham, 2015) antara lain menentukan pemerintahan secara langsung maupun tidak langsung, sebagai wahana umpan balik antara pemilik suara dan pemerintah, barometer dukungan rakyat terhadap penguasa, sarana rekruitmen politik serta alat untuk mempertajam kepekaan pemerintah terhadap tuntutan rakyat. 
Accessible dalam kamus Merriam-Webster (1828) didefinisikan sebagai kata sifat yang memiliki arti seperti dapat dijangkau, mudah dihadapi, mampu digunakan atau dilihat (tersedia), mampu dipahami atau dihargai, mampu dipengaruhi (terbuka), serta mudah digunakan atau diakses oleh penyandang disabilitas (diadaptasi untuk digunakan oleh para penyandang disabilitas). Sedangkan menurut Kentingan (2011:11) (Dwintari, 2018), aksesibilitas adalah kemudahan yang disediakan bagi penyandang disabilitas guna mewujudkan kesamaan kesempatan dalam segala aspek kehidupan dan penghidupan. Berdasarkan teori tersebut yang dimaksud dengan aksesibilitas adalah suatu kemudahan untuk penyandang disabilitas yang digunakan untuk mewujudkan kesamaan kesempatan dalam seluruh aspek kehidupan termasuk kehidupan berpolitik. Aksesibilitas dilihat dari penyelenggaraan Pemilu 2019, akan digunakan teori Akesibilitas Pelayanan menurut Penchansky \& Thomas (1984) (Laksono et al., 2016):

Ketersediaan (availability) dalam ketersediaan terdapat empat komponen yang dapat dilihat yaitu meliputi Man, Material, Method dan Machine. Ketersediaan Man adalah adanya sumber daya manusia penunjang pelayanan. Ketersediaan Material yang dimaksud adalah ketersediaan logistik yang memadai sesuai dengan kebutuhan penyandang disabilitas. Ketersediaan Method berhubungan dengan cara pelayanan yang dilakukan oleh petugas seperti efisiensi waktu dalam memberikan pelayanan. Dan ketersediaan Machine berkaitan dengan ketersediaan peralatan pendukung pelayanan atau fasilitas pendukung seperti sarana prasarana sesuai dengan kebutuhan.

Aksesibilitas (accessibility) adalah fasilitas yang tersedia bagi penyandang disabilitas mudah dijangkau, mudah digunakan secara mandiri oleh penyandang disabilitas yang terdiri dari aksesibilitas fisik dan non-fisik. Aksesibilitas fisik adalah suatu kemudahan untuk mengakses fasilitas umum. Sedangkan aksesibilitas non fisik adalah suatu kemudahan yang diberikan bagi semua orang untuk dapat dengan mudah mengakses pelayanan informasi.

Akomodasi (accommodation) yaitu berkaitan dengan sistem pelayanan Tempat Pemungutan Suara yang berhubungan dengan kemudahan pemanfaatan (jam buka pengunjung, waktu tunggu pelayanan dan panjangnya waktu tunggu untuk janji pelayanan)

Keterjangkauan (affordability) yaitu kemampuan finansial pemilih penyandang disabilitas sebagai pengguna layanan Tempat Pemungutan Suara untuk memanfaatkan pelayanan, apabila dalam pengadaan pelayanan membutuhkan biaya administrasi.

Akseptabilitas (acceptability), dalam hal ini direpresentasikan dengan sikap pemilih penyandang disabilitas sebagai pengguna hak pilih terhadap pelayanan petugas Tempat Pemungutan Suara dan sebaliknya.

\section{Penelitian terdahulu}

Kajian mengenai aksesibilitas penyandang disabilitas dalam pemilu pernah dilakukan oleh Lisa Schur, Mason Ameri, dan Meera Adya (2017) (Schur et al., 2017), dimana dalam penelitian tersebut memperlihatkan aksesibilitas di tempat pemungutan suara yang kurang aksesibel sehingga menurunkan jumlah partisipasi penyandang disabilitas. Dimana metode yang digunakan adalah Voting and Registration (VRS). Penelitian lain juga pernah dilakukan oleh Bhavisha Virendrakumar, Emma Jolley, Eric Badu dan Elena Schmidt (2018) (Virendrakumar et al., 2018). Penelitiannya menjelaskan mengenai temuan bahwa Afrika yang meratifikasi regulasi tentang hak-hak disabilitas namun masih rendahnya partisipasi dalam bidang politik terutama hak dalam pelaksanaan Pemilu.

Penelitian yang dilakukan di Eropa oleh Mark Priestley, Martha Stickings, Ema Loja, Stefanos Grammenos, Lisa Waddington, Bjarney Fridriksdottir, dan Anna Lawson (2016) (Priestley et al., 2016) mengungkapkan bahwa disabilitas adalah variabel sosial ekonomi yang hilang dalam penelitian partisipasi politik. Temuan dari penelitian yakni kesetaraan politik dan hak memilih ditolak untuk beberapa kelompok penyandang cacat dalam hukum nasional. Hambatan dan modal sosial 
berinteraksi dengan efek penurunan nilai pada partisipasi politik.

Sementara penelitian di Indonesia yang dilakukan Junaidi Abdillah (2015) (Abdillah, 2015) menyebutkan bahwa pelaksanaan pemilu di Indonesia pada tahun 2004 sampai dengan pemilu tahun 2014 bentuk penghormatan, perlindungan dan pemenuhan hak-hak politik penyandang disabilitas melalui pemilu aksesibel dan non-diskrimanasi secara bertahap telah mengalami peningkatan yang cukup signifikan meskipun masih terdapat hambatan yang membatasi dan menghilangkan hak politik penyandang disabilitas.

\section{Metode}

Penelitian ini merupakan penelitian deskriptif kualitatif yang bertujuan untuk melihat dan memahami fakta yang terjadi terkait aksesibilitas penyandang disabilitas dalam pelaksanaan Pemilu 2019 di Kabupaten Sleman. Penelitian ini dilakukan di Kabupaten Sleman, karena merupakan salah satu dari lima Kabupaten/Kota di Provinsi Daerah Istimewa Yogyakarta yang telah menetapkan peraturan daerah tentang hak-hak penyandang disabilitas dalam Peraturan Daerah Kabupaten Sleman Nomor 1 Tahun 2018. Dalam penelitian ini terdapat dua sumber data, yakni data primer berasal dari wawancara dengan informan serta data sekunder yang berisi dokumentasi. Teknik pengambilan informan pada penelitian ini menggunakan purposive sampling. Informan yang diwawancarai dalam penelitian ini adalah anggota KPU Kabupaten Sleman, anggota BAWASLU Kabupaten Sleman, anggota KPPS Desa, Direktur organisasi CIQAL, anggota organisasi SIGAB, serta pemilih dengan disabilitas netra dan intelektual. Dalam menganalisis data yang telah diperoleh, peneliti menggunakan teknik analisis model interaktif dari Miles dan Huberman.

\section{Hasil dan Pembahasan}

Pemilu merupakan salah satu sarana yang diberikan oleh negara kepada seluruh rakyat Indonesia untuk memilih anggota legislatif maupun eksekutif secara langsung, umum, bebas, rahasia, jujur, dan adil yang telah dijamin dalam Pancasila dan Undang-Undang Dasar 1945. Pemilu 2019 diadakan secara serentak yang dalam pelaksanaannya Pemilihan Legislatif (Pileg) dan Pemilihan Presiden dan Wakil Presiden (Pilpres) dilaksanakan pada tanggal yang sama, yaitu 17 April 2019. Konsep Pemilu inklusif secara normatif juga diterapkan pada Pemilu 2019, dengan mengakomodasi hak-hak penyandang disabilitas dalam menyalurkan suaranya dalam pesta demokrasi.

Untuk mengetahui bagaimana penyelenggaraan pemilihan umum yang aksesibel terhadap penyandang disabilitas di Kabupaten Sleman, peniliti menggunakan kriteria yang sebagaimana disampaikan oleh Penchansky \& Thomas (1981). Adapun dimensi untuk mengetahui pemilu yang akses yakni berkaitan dengan accessibility, accomodation, availability, dan acceptability. Berdasarkan penelitian di lapangan dapat dirumuskan analisis sebagai berikut.

\section{Aksesibilitas (Accesibility)}

Accessibility atau aksesibilitas yang dimaksud adalah fasilitas yang tersedia bagi penyandang disabilitas mudah dijangkau, mudah digunakan secara mandiri oleh penyandang disabilitas. Demartoto (Seto, 2015). Aksesibilitas pelayanan publik dibagi ke dalam dua macam yaitu aksesibilitas fisik dan aksesibilitas non fisik. Jika dikaitkan dengan Pemilu 2019, aksesibilitas fisik terdiri dari sarana dan prasarana penunjang seperti tempat pemungutan suara serta berbagai kelengkapan dan ketersediaan yang dibutuhkan oleh pemilih. Sedangkan aksesibilitas non fisik meliputi standar pelayanan aksesibilitas pemilu dan informasi berkenaan dengan pemilu.

Berkaitan aksesibilitas non fisik, komisioner KPU Sleman mengatakan sebagai berikut:

"KPU sudah beberapa kali melakukan sosialisasi pemilu bersama penyandang disabilitas. Untuk petugas di kami sudah sosialisasikan tentang teknis selama pemungutan suara terutama cara menangani pemilih penyandang disabilitas. Jadi kami sudah usahakan semaksimal mungkin agar 
Public Inspiration: Jurnal Administrasi Publik, 6 (1) (2021), 35

Aksesibilitas Penyandang Disabilitas dalam Pemilu 2019 di Kabupaten Sleman

inklusif, baik dari segi informasi maupun saat penyelenggaraannya."

Beberapa penyandang disabilitas yang dikonfirmasi membenarkan pernyataan penyelenggara Pemilu tersebut, meskipun sebagian diantaranya tidak bisa mengikuti sosialisasi karena keterbatasan mobilitas.

Meski telah diupayakan KPU, proses sosialisasi Pemilu bukan tanpa hambatan. Terbatasnya jumlah petugas KPU yang memiliki kemampuan untuk berkomunikasi dengan bahasa isyarat bagi penyandang tuna rungu dan tuna wicara menyebabkan sosialisasi menjadi kurang maksimal. Keberadaan mitra yang berkompeten diperlukan KPU untuk mensosialisasikan Pemilu kepada penyandang disabilitas. Sebagaimana dinyatakan pegiat dari Yayasan CIQAL yang mengutarakan bahwa dari pihak yayasan turut membantu dalam mensosialisasikan Pemilu kepada kelompok penyandang disabilitas.

Pada dasarnya, pengadaan sosialisasi yang optimal mengenai penyelenggaraan Pemilu merupakan salah satu bentuk pemberian akses kepada para penyandang disabilitas, yakni aksesibilitas non-fisik yang berkaitan dengan hak akses atas informasi.

Selain aksesibilitas non-fisik, aksesibilitas fisik juga menjadi faktor paling penting dalam mewujudkan penyelenggaraan Pemilu yang inklusif. Pada penyelenggaraan Pemilu 2019 di Kabupaten Sleman, KPU selaku pihak penanggung jawab menyatakan telah mengupayakan keseluruhan fasilitas agar aksesibel bagi seluruh elemen masyarakat, khususnya penyandang disabilitas. Namun, hal tersebut dibantah oleh pihak Yayasan CIQAL yang mengatakan Pemilu di Kabupaten Sleman belum inklusif bagi penyandang disabilitas. Pendapat pihak Yayasan CIQAL senada dengan penilaian pihak Bawaslu. Menurut Bawaslu, pada saat pencoblosan berlangsung, pemilih dengan disabilitas belum terfasilitasi sepenuhnya. Hal tersebut dijelaskan secara terperinci oleh pihak Bawaslu Kabupaten Sleman sebagai berikut:

"Aksesbilitas yang diterima penyandang disabilitas dalam Pemilu 2019 menurut Bawaslu Sleman belum sepenuhnya terfasilitasi terutama saat proses pencobolosan berlangsung. Tuna netra yang harus berjalan memakai alat bantu misalnya aksesnya belum bagus, tidak ada jalan khusus, meja kotak suara yang tidak aksesibel, dsb. Bagi tuna rungu, belum adanya fasilitas yang membantu penyandang disabilitas ini mendengarkan siapa calon-calon yang maju, dan mereka hanya melalui feeling atau kata keluarga untuk menentukan hak pilihnya. Tuna daksa yang harus melalui jalan tidak ramah disabilitas, terdapat jalan berundak, dan bertempat di ruang yang sulit dijangkau oleh penyandang disabilitas ini."

Kaitannya dalam mengupayakan aksesibilitas fisik, dalam penyelenggaraan Pemilu telah terdapat pedoman dalam membuat TPS agar dapat aksesibel bagi seluruh masyarakat khususnya penyandang disabilitas. Jarak antar meja dan ukuran pintu masuk maupun keluar telah diatur sedemikian rupa agar dapat memudahkan mobilitas pemilih. Namun pada pelaksanaannya, masih terdapat TPS yang berundak-undak sehingga menyulitkan pengguna kursi roda dalam mengakses TPS. Sedangkan untuk aksesibilitas non-fisik, KPU Kabupaten Sleman telah menyelenggarakan sosialisasi Pemilu secara khusus bagi para penyandang disabilitas, namun masih terdapat pemilih disabilitas yang tidak mendapat akses sosialisasi karena keterbatasan mobilitas.

\section{Akomodasi (Accomodation)}

Akomodasi (accommodation), yaitu berkaitan dengan sistem pelayanan Tempat Pemungutan Suara yang berhubungan dengan kemudahan pemanfaatan (jam buka pengunjung, waktu tunggu pelayanan dan panjangnya waktu tunggu untuk janji pelayanan). Pemilu 2019 di Kabupaten Sleman dilaksanakan mulai pukul 07.00 WIB sampai dengan pukul 13.00 WIB yang kemudian segera dilanjutkan dengan penghitungan surat suara. Selain hal tersebut, adanya pemahaman bahasa maupun interpretasi dalam pengadaan pelayanan perlu diketahui, yakni dalam hal proses pemungutan suara di 
Tempat Pemungutan Suara yang mana didalamnya terdapat istilah-istilah yang perlu disampaikan dengan bahasa secara khusus kepada pemilih penyandang disabilitas sesuai dengan keterbatasan dan kebutuhan yang dimiliki.

Pihak KPU Sleman yang mengatakan bahwa:

"Untuk waktu pelaksanaan pemilihan sudah sesuai dengan jadwal mbak, dan alhamdulillah berjalan dengan lancar tanpa kendala. Jadi petugas sudah stand-by di TPS selanjutnya pemilihan sendiri dibuka pukul 07.00 WIB kemudian ditutup pada pukul 13.00 WIB. Kemudian dilakukan proses penghitungan suara. Dari pantauan kami, seluruh pemilih yang terdaftar dan memiliki undangan diberikan hak pilih dan dilayani pada jam tersebut sampai DPT yang hadir di TPS sudah habis begitu juga surat suaranya. Jadi untuk penyandang disabilitas yang datang ke TPS juga dilayani dan diberikan surat suara. Selain itu kami juga sudah menginformasikan hal-hal penting yang berkaitan dengan pemilu itu sendiri mulai dari surat suara, calon presiden dan wakil, calon wakil DPR, DPRD Provinsi maupun DPRD Kabupaten/Kota sejelas mungkin sehingga diharapkan tidak terjadi mis komunikasi."

Berbeda dengan yang disampaikan pihak Yayasan CIQAL yang justru menegaskan bahwa penyelenggaraan Pemilu belum aksesibel sistem pelayanannya.

"Dari kami sendiri mengidentifikasi belum akses sistem pelayanannya. Jika sudah akses seharusnya seluruh pemilih disabilitas yang terdaftar dalam DPT mendapatkan pelayanan yang sama seperti yang lainnya. Tapi ini ada satu orang yang ketinggalan, kalau memang memegang prisip pemilu akses kenapa tidak diusahakan supaya bisa menyalurkan hak pilihnya. Nyatanya petugas hanya bilang kalau surat suara sudah habis, jadi TPS ditutup dan disuruh pulang karena sudah tutup."

Seorang penyandang disabilitas intelektual, yang pada saat pelaksanaan Pemilu mendapatkan pelayanan yang kurang baik terkait tenggat waktu tunggu dalam memberikan suara menyatakan sebagai berikut.

"Iya waktu itu udah datang dari pagi, udah antri. Tapi gak dipanggil-panggil sama petugasnya sampai siang. Padahal antri saya dari pagi."

Meskipun pelaksanaan Pemilu telah terjadwal, pada kenyataannya masih terdapat ketidakadilan yang di alami oleh pemilih disabilitas, yakni adanya pemilih yang tidak bisa mendapatkan hak pilihnya dengan alasan surat suara yang disediakan oleh KPPS sudah habis. Padahal pemilih yang bersangkutan telah menunggu dari pagi hingga TPS tutup untuk memberikan suaranya.

\section{Ketersediaan (Availability)}

Ketersediaan meliputi empat komponen yaitu man, material, method dan machine. Mengacu pada data mengenai jumlah petugas pada Pemilu 2019 yang telah disediakan oleh KPU Kabupaten Sleman dengan jumlah PPK sebanyak 85 orang, PPS sebanyak 258 orang, dan KPPS sebanyak 30.528 orang dapat disimpulkan bahwa ketersediaan man sudah cukup memadai, mengingat jumlah DPT yaitu 774.609 orang dengan penyandang disabilitas sejumlah 2.922 orang. Selain PPS, PPK, dan KPPS, KPU Kabupaten Sleman juga melakukan rekrutmen calon relawan demokrasi (Relasi) secara terbuka sebanyak 55 orang dari total pelamar 157 orang.

Pemilihan Umum akan dikatakan aksesibel terhadap penyandang disabilitas jika tercukupi ketersediaan man, dimana dengan ketersediaan man atau petugas TPS yang memadai seluruh penyandang disabilitas dapat terlayani pada saat pemilihan umum berlangsung. Sehingga penyandang disabilitas dapat menyalurkan hak suara mereka pada pemilu 2019 secara Luber Jurdil.

Menurut komisioner KPU Kabupaten Sleman menjelaskan bahwa:

"KPU telah menyediakan petugas yang cukup untuk pelaksanaan pemilu tahun 2019. Kami sediakan banyak petugas, agar semua dapat terlayani dengan baik. Sudah kami briefing semua 
petugasnya sebelum hari pemilu sesuai masing-masing jobnya. Mereka juga sudah diberitahu jika ada penyandang disabilitas harus bagaimana cara melayaninya."

Ketersediaan man juga terkonfirmasi dari pendapat pihak Bawaslu dan LSM Sasana Inklusi dan Gerakan Advokasi Difabel (SIGAB) Yogyakarta yang melakukan pemantauan terhadap Pemilu akses. Ketersediaan petugas pada keseluruhan Tempat Pemungutan Suara (TPS) tidak mengalami permasalahan karena jumlahnya yang tercukupi dan dibantu oleh keberadaan relawan demokrasi.

Ketersediaan material dalam Pemilu berkaitan dengan tersedianya logistik pada saat pelaksanaan pemilihan, yang meliputi surat suara, alat bantu coblos, kotak suara, template suara bagi penyandang disabilitas, serta alat bantu coblos bagi penyandang disabilitas. Pemilihan umum dikatakan akses terhadap penyandang disabilitas apabila memenuhi ketersediaan material tersebut. berikut:

Menyangkut ketersediaan logistik Pemilu, pihak KPU Kabupaten Sleman menjelaskan sebagai

"Untuk kebutuhan logistik sudah disiapkan semua, sudah di list jauh-jauh hari untuk dimintakan kepada KPU Pusat. Disediakan juga untuk penyandang disabilitas, termasuk template untuk disabilitas netra dan surat suaranya."

Berdasarkan pengawasan yang dilakukan oleh Bawaslu Kabupaten Sleman beserta jajaran di kecamatan dan desa serta pengawas TPS, pihak Bawaslu menjelaskan sebagai berikut:

"Informasi yang beredar di masyarakat bahwa template yang disediakan oleh KPU hanya untuk surat suara presiden dan wakil presiden saja dan/atau ditambah surat suara untuk DPR RI, sementara jenis surat suara untuk DPD, DPRD Provinsi dan DPRD Kabupaten/Kota tidak ada templatenya. Penelusuran yang dilakukan oleh Pengawas sebatas petugas KPPS menginformasikan saat pembukaan TPS bila template untuk penyandang disabilitas masuk dalam kotak dan tersedia, tidak disebutkan jumlah dan jenisnya. Penyandang disabilitas juga tidak menyampaikan komplain terhadap petugas KPPS ataupun pengawas sehingga dimungkinkan tidak ada masalah dengan template."

Penjelasan pihak LSM SIGAB melengkapi pendapat dari Bawaslu sebagai berikut:

"KPU sendiri sebenarnya sudah berusaha semaksimal mungkin untuk membuat template. Tapi kalau yang DPR/DPRD juga dibikinkan template nanti sebesar apa itu. Kasihan disabilitas netranya mbak. Orang yang non disabilitas saja kesusahan untuk membuka surat suaranya, sudah begitu bingung karena banyaknya calon. Jadi yang tuna netra cuma dibuatkan template untuk presiden dan wakil presiden sama template surat suara DPD."

Dari uraian tersebut dapat diketahui bahwa KPU selaku penyelenggara sudah berupaya semaksimal mungkin untuk mempermudah penyandang disabilitas maupun non disabilitas agar Pemilu 2019 berjalan aksesibel. Namun, dalam penyediaan surat suara maupun template untuk penyandang tuna netra masih dapat dikatakan belum aksesibel.

Ketersediaan machine dalam Pemilu yang aksesibel bagi penyandang disabilitas terkait dengan ketersediaan seperti halaman parkir, tempat pemungutan suara yang aksesibel, ruang tunggu, penyediaan moda antar jemput dari rumah menuju TPS dan sebaliknya bagi penyandang disabilitas.

Menyangkut ketersediaan hal tersebut pihak KPU Kabupaten Sleman berpendapat:

"Kita sudah menyediakan. Yang tidak disediakan itu moda antar jemputnya, karena menurut kami, letak TPS yang disediakan sudah diatur supaya seluruh masyarakat termasuk penyandang disabilitas dapat menjangkau TPS yang telah disediakan."

Berbeda dengan penuturan pihak KPU, pihak Yayasan CIQAL menyatakan sebagai berikut:

"Masih banyak yang membutuhkan bantuan mobilitas. Dari temuan lapangan yang diperoleh berdasarkan penelusuran difabike (semacam organisasi ojek yang supirnya penyandang disabilitas), 
Public Inspiration: Jurnal Administrasi Publik, 6 (1) (2021), 38

Aksesibilitas Penyandang Disabilitas dalam Pemilu 2019 di Kabupaten Sleman

Desa Sidoluhur dan Sidomoyo Kecamatan Godean, Desa Sendangadi Kecamatan Mlati dan Desa Donoharjo Kecamatan Ngaglik ada 23 orang pemilih yang membutuhkan bantuan mobilitas. Yayasan bersama Difabike dan relawan Gandem mengeluarkan 15 orang relawan, 6 unit sepeda motor roda tiga untuk membawa kursi roda, 12 unit kursi roda, 2 unit sepeda motor, dan 3 unit mobil.”

Pendapat senada disampaikan pihak LSM SIGAB sebagai berikut:

"Kalau ketersediaan fasilitas di TPS sudah cukup, hanya saja memang dari pihak penyelenggara tidak menyediakan alat bantu mobilitas dari rumah ke TPS. Padahal para pengguna kursi roda dan tuna daksa lainnya jumlahnya cukup banyak. Yang lumpuh juga ada. Jadi mungkin kekurangannya disitu."

Dari uraian diatas, diatas dapat diketahui bahwa penyelenggaraan Pemilu 2019 di Kabupaten Sleman dari segi ketersediaan machine belum aksesibel bagi penyandang disabilitas. Hal tersebut dibuktikan dengan adanya temuan bahwa masih adanya hambatan mobilitas penyandang disabilitas dalam menjangkau TPS dari beberapa wilayah di Kabupaten Sleman. TPS yang ada juga tidak menyediakan fasilitas antar jemput bagi penyandang yang kesulitan dalam mobilitas. Meskipun solusi atas masalah tersebut telah dibantu oleh yayasan CIQAL serta relawan lainnya dalam menyediakan fasilitas antar jemput pemilih.

Ketersediaan method dalam pemilu yang aksesibel bagi penyandang disabilitas berkaitan dengan metode yang digunakan petugas TPS dalam melayani penyandang disabilitas pada saat pemilihan berlangsung. Standar pelayanan yang dilakukan petugas TPS mengacu pada buku Panduan KPPS Pemungutan dan Penghitungan Suara Pemilu tahun 2019 yang telah disediakan oleh KPU, sehingga seluruh petugas akan menjalankan standar pelayanan sesuai yang telah ditetapkan. Salah satu ketentuan dalam aturan tersebut adalah bahwa pemilih dengan disabilitas harus memiliki prioritas untuk dilayani oleh petugas pemungutan suara karena keterbatasan fisik dapat menghambat mereka dalam memberikan hak suaranya dalam Pemilu.

Namun dalam kenyataannya, Yayasan CIQAL masih menemukan penyandang disabilitas yang tidak mendapatkan pelayanan sama sekali dari pihak petugas di TPS, sebagaimana penuturan berikut:

"Terdapat seorang penyandang disabilitas di Godean yang sama sekali tidak diberi pelayanan. Dia punya surat undangan, datang dari pagi, nunggu sampai jam 1 tapi tidak dipanggil-panggil. Kemudian dia tanya sama petugas, katanya TPS sudah tutup karena surat suaranya habis.”

Realitas hampir serupa dialami oleh seorang pemilih dengan disabilitas intelektual yang mengutarakan sebagai berikut:

"Saya sudah antri dari pagi, tapi dilayaninya lama sekali. Padahal petugas TPS sudah melihat saya datang dari pagi."

Dari pernyataan yang dikemukakan tersebut, dapat diketahui bahwa masih ditemukan perlakuan diskriminatif pada sebagian TPS di Kabupaten Sleman terhadap pemilih dengan disabilitas. Padahal dalam konsep Pemilu inklusif terdapat anjuran bahwa semua warga masyarakat harus diperlakukan dengan setara dan adil dalam memberikan hak pilihnya tanpa membeda-bedakan. Terutama bagi pemilih disabilitas yang membutuhkan prioritas untuk mendapatkan akses hak politiknya karena keterbatasan yang dimilikinya.

\section{Akseptabilitas (Acceptability)}

Acceptability atau penerimaan, dalam hubungannya dengan pemilu yang akses terhadap penyandang disabilitas diartikan sebagai sikap yang ditunjukkan oleh petugas di TPS kepada pemilih dengan disabilitas maupun sebaliknya yakni sikap penerimaan oleh penyandang disabilitas yang ditunjukkan kepada para petugas di tempat pemungutan suara.

Seorang petugas KPPS di salah satu TPS di Kabupaten Sleman yang terdapat penyandang 
disabilitas di TPS tempatnya bertugas menyatakan sebagai berikut:

"Kemarin pemilu disini sudah berjalan lancar mbak, semua penyandang disabilitas juga sudah dilibatkan dalam pemilu. Jadi ya mereka tetap menyumbangkan hak pilih mereka walaupun mereka punya keterbatasan. Di daerah saya ini penyandang disabilitasnya bervariatif mbak, ada yang tunanetra, ada yang ODGJ (orang dengan gangguan jiwa). Paling banyak disini sih yang ODGJ itu mbak, soalnya mereka itu ada yang satu keluarga ODGJ semua. Tapi walaupun mereka punya keterbatasan sebagai penyandang ODGJ tetap diberikan hak untuk memilih. Mereka dilayani juga pada saat pencoblosan. Cuma dari masyarakat umumnya yang masih memandang sebelah mata penyandang ODGJ, yang dianggap sama dengan orang gila."

Menurut salah satu warga penyandang tuna netra mengenai sikap penerimaan yang ditunjukkan para petugas di tempat pemungutan suara berpendapat:

"Iya baik, saya diperbolehkan memilih. Iya pada saat pemilu. Iya mereka baik".

Hal tersebut juga dibenarkan oleh salah satu informan penyandang disabilitas intelektual yang mendapatkan hak pilih:

"Iya mbak, saya dilayani dengan baik. Saya datang diantar kakak saya ke TPS, disana saya diberi surat suara juga. Mereka juga ramah. Saya senang-senang saja disana."

Pendapat dari pihak Yayasan CIQAL sedikit berbeda, bahwa:

"Belum inklusif mbak, memang dari pihak penyelenggara sudah berupaya semaksimal mungkin agar inklusif terhadap kaum difabel namun menurut saya mereka belum sepenuhnya inklusif. Masih ada di beberapa tempat pemungutan suara yang petugasnya tidak ramah terhadap penyandang disabilitas mbak. Masih ada penyandang disabilitas yang tidak dilayani, karena menurut petugas tidak ada di daftar pemilih meski punya undangan sebagai pemilih."

Sedangkan menurut salah satu anggota SIGAB menjelaskan bahwa:

"Menurut saya pribadi, karna saya juga salah satu bagian dari penyandang disabilitas mbak jadi saya mengalaminya langsung juga. Jadi sebenarnya KPU sendiri sebagai penyelenggara sudah berusaha dan mengupayakan semaksimal mungkin agar pelaksanaan pemilu tahun 2019 yang lalu inklusif. Dari petugas sendiri sudah mengikuti prosedur yang seharusnya. Hanya saja persepsi masyarakat terhadap penyandang disabilitas dipandang lebih rendah dibanding masyarakat normal pada umumnya yg memiliki fisik maupun psikis yang sempurna."

Akses penyandang disabilitas dalam Pemilu 2019 di Kabupaten Sleman dilihat dari dimensi acceptability sudah diupayakan oleh KPU, namun belum sepenuhnya aksesibel dan ramah terhadap penyandang disabilitas. Hal tersebut dibuktikan dengan masih adanya perlakuan yang tidak adil terhadap pemilih dengan disabilitas, termasuk dari persepsi sebagian masyarakat.

Apabila melihat uraian mengenai akses pemilu untuk penyandang disabilitas dari perspektif accessibility, accomodation, availability, dan acceptability tersebut dapat ditarik benang merah bahwa akses pemilu untuk penyandang disabilitas masih belum optimal, terutama dalam memberikan perlindungan hak sebagai pemilih. Pada dasarnya, dengan menghilangkan hak penyandang disabilitas untuk memilih dalam Pemilu sama dengan menghilangkan hak warga negara dalam memberikan hak politiknya.

Dalam dokumen The Bill of Electoral Right for Citizen with Disabilities disebutkan bahwa setiap warga negara memiliki hak dan kesempatan yang sama tanpa pembedaan atas dasar disabilitas yang disandangnya baik secara fisik, intelektual, sensorik, mental atau lainnya untuk berpartisipasi berdasarkan persyaratan umum tentang persamaan hak dalam melakukan pemilihan (Abdillah, 2015). Penyediaan akses layanan merupakan hal yang penting dan harus diupayakan dalam pelayanan publik (Amalia, 2020; Dewi, 2020). 
Public Inspiration: Jurnal Administrasi Publik, 6 (1) (2021), 40

Aksesibilitas Penyandang Disabilitas dalam Pemilu 2019 di Kabupaten Sleman

Menilik dari komitmen KPU dalam penyediaan akses politik sebagai wujud penerjemahan kesetaraan hak bagi penyandang disabilitas dalam (Mais \& Yaum, 2019), telah tercantum bahwa : a) KPU memberikan ruang yang sama kepada seluruh warga negara dalam berpartisipasi dalam pemilu; b) KPU berkomitmen untuk memberikan ruang yang sama dalam pemenuhan hak penyandang disabilitas yang meliputi hak politik, hak aksesibilitas, pelayanan publik, pendataan, berekspresi, berkomunikasi, bebas dari tindakan diskriminasi serta hak untuk memperoleh informasi; dan c) dalam penyelenggaraan setiap tahapan Pemilu, KPU harus memperhatikan aksesibilitas disabilitas untuk memperhatikan hak-hak politiknya agar dapat terpenuhi dengan baik.

KPU juga telah berkomitmen dengan menandatangani nota kesepahaman dengan PPUA PENCA (Pusat Pemilu Akses Penyandang Cacat) yang merupakan lembaga advokasi hak politik penyandang disabilitas Indonesia pada tanggal 11 Maret 2013. Dalam nota kesepahaman tersebut, KPU berjanji akan menyelenggarakan setiap tahapan pemilu secara inklusif, aksesibel dan nondiskriminatif khususnya bagi penyandang disabilitas. Bercermin dari komitmen tersebut, penyelenggara Pemilu hingga tingkat TPS perlu melakukan perbaikan serta lebih memperkuat mindset organisasinya agar lebih mampu menyelenggarakan Pemilu secara aksesibel bagi penyandang disabilitas untuk Pemilu selanjutnya.

Riewanto (2018) dalam (Andriani \& Amsari, 2021) menyatakan bahwa kurangnya perhatian dan terjadinya tindakan diskriminatif pada kelompok penyandang disabilitas secara sistemik merupakan salah satu permasalahan yang sulit untuk diatasi dalam Pemilu di Indonesia. Meskipun telah terdapat regulasi dan mekanisme yang melindungi hak pilih kelompok penyandang disabilitas, namun hal tersebut tidak mencegah pelanggaran dan tidak terpenuhinya hak mereka sebagai warga negara dalam Pemilu. Stigma masyarakat serta struktur sosial yang ada seringkali menganggap remeh aspirasi dari kelompok penyandang disabilitas. Lebih lanjut dalam penelitian Riewanto (2018) juga ditemui permasalahan yang sama dengan yang terjadi di Kabupaten Sleman, bahwa masih terdapat pemilih penyandang disabilitas yang tidak terdaftar sebagai pemilih karena keengganan petugas pendaftaran pemilih (Pantarlih) untuk mendaftarkan pemilih disabilitas. Sehingga yang bersangkutan kehilangan hak suaranya akibat stigma sebagian masyarakat yang masih belum menerima dan mampu memperlakukan dengan baik para penyandang disabilitas.

Dalam konteks tersebut, semua pihak sebaiknya melihat kembali UU Nomor 19 Tahun 2011 tentang Pengesahan Convention On The Rights of Person of Disabilities, dimana dalam regulasi tersebut dinyatakan bahwa salah satu hak politik yang harus didapatkan oleh penyandang disabilitas adalah hak untuk memberikan suara dan aspirasi dalam setiap kebijakan pemerintah. Selain memberikan kesempatan dalam berpolitik tentu saja pemerintah berkewajiban untuk mengakomodasi akses penyandang disabilitas dalam proses memberikan aspirasi atau suaranya. Berdasarkan kajian di atas, saran bagi penyelenggara pemilihan umum, KPU beserta jajaran hingga tingkat TPS sebaiknya lebih memperhatikan akses bagi penyandang disabilitas, khususnya mengenai keterjangkauan TPS, ketersediaan sarana dan prasarana, ketersediaan standard operational procedure (SOP) pelayanan bagi penyandang disabilitas, serta kecakapan dan kesigapan petugas dalam menghadapi pemilih disabilitas. Bagi masyarakat, disarankan merubah mindset terhadap penyandang disabilitas sehingga lebih ramah dalam mendukung penyandang disabilitas untuk menggunakan hak pilihnya.

\section{Simpulan}

Berdasarkan hasil penelitian dan analisa yang telah dilakukan, Pemilu tahun 2019 di Kabupaten Sleman belum aksesibel untuk penyandang disabilitas. Hal tersebut dikarenakan dalam dimensi aksesibilitas (accessibility) terdapat fakta bahwa TPS yang disediakan oleh KPU belum seluruhnya akses. Masih ada beberapa TPS yang tidak akses untuk penyandang disabilitas, seperti masih terdapat undak-undakan atau tangga yang menyulitkan penyandang disabilitas daksa dalam memasuki TPS. Demikian pula dalam dimensi akomodasi (accommodation), pelayanan petugas TPS masih ada yang 
Public Inspiration: Jurnal Administrasi Publik, 6 (1) (2021), 41

Aksesibilitas Penyandang Disabilitas dalam Pemilu 2019 di Kabupaten Sleman

belum akses terhadap penyandang disabilitas, seperti adanya penyandang disabilitas yang tidak mendapatkan pelayanan akibat surat suara habis, serta permasalahan terkait keterbatasan komunikasi. Dimensi ketersediaan (availability) belum cukup akses bagi penyandang disabilitas, terutama ketersediaan material, machine, dan method. Ketersediaan material yang belum akses untuk penyandang disabilitas misalnya template surat suara bagi penyandang disabilitas yang hanya tersedia dua template surat suara. Keterbatasan ketersediaan machine berupa minimnya sarana penunjang mobilitas penyandang disabilitas dalam menjangkau TPS di beberapa wilayah di Kabupaten Sleman. Ketersediaan method juga masih belum akses bagi penyandang disabilitas, terlihat dari kurangnya prioritas penyandang disabilitas untuk mendapatkan akses hak memilih. Dimensi akseptabilitas (acceptability) atau penerimaan belum cukup aksesibel bagi penyandang disabilitas, terutama karena masih adanya persepsi kurang tepat dari sebagian masyarakat terhadap penyandang disabilitas.

\section{Daftar Pustaka}

Abdillah, J. (2015). Pelaksanaan Pemilu Yang Aksesibel dan Non-Diskriminasi Sebagai Upaya Pemenuhan Hak-Hak Politik Penyandang Disabilitas. Jurnal HAM, 6(1), 39-49.

Amalia, F. R. (2020). Efektivitas Inovasi "One Day Service" Dalam Penerbitan Akta Kelahiran di Dinas Kependudukan dan Pencatatan Sipil Kabupaten Tabanan. Public Inspiration: Jurnal Administrasi ..., 5 (2), 121-144.

Andriani, H., \& Amsari, F. (2021). Hak Pilih Kelompok Penyandang Disabilitas Dalam Pemilihan Umum Tahun 2019 Di Sumatera Barat. Jurnal Konstitusi, 17(4), 777-798.

Dewi, I. (2020). Inovasi Pelayanan Publik "Sapaku Malam” di Kecamatan Kuta Utara, Kabupaten Badung. Public Inspiration: Jurnal Administrasi Publik, 5(2), 104-120.

Dwintari, J. W. (2018). Aksesibilitas Penyandang Disabilitas dalam Pemilihan Umum di Indonesia. JISIPUNJA| Jurnal Ilmu Sosial Dan Ilmu Politik Fisipol Universitas Jambi, 1(2), 24-53.

Kurniawan, H., \& Forestyana, S. (2017). Perancangan Aksesibilitas untuk fasilitas publik. Yogyakarta: Gajah Mada Univercity Press.

Labolo, M., \& Ilham, T. (2015). Partai Politik dan Sistem Pemilihan Umum di Indonesia. Rajawali Pers.

Laksono, A. D., Mubasyiroh, R., Laksmiarti, R., Suharmiati, E. N., \& Sukoco, N. E. (2016). Aksesibilitas Pelayanan Kesehatan di Indonesia. Yogyakarta: PT Kanisius.

Mais, A., \& Yaum, L. A. (2019). Aksesibiltas dan Partisipasi Politik Penyandang Disabilitas di Kabupaten Jember. Kaganga: Jurnal Pendidikan Sejarah Dan Riset Sosial-Humaniora, 2(2), 78-87.

Priestley, M., Stickings, M., Loja, E., Grammenos, S., Lawson, A., Waddington, L., \& Fridriksdottir, B. (2016). The political participation of disabled people in Europe: Rights, accessibility and activism. In Electoral Studies (Vol. 42). https://doi.org/10.1016/j.electstud.2016.01.009

Salim, I. (2015). Difabel merebut bilik suara: kontribusi gerakan difabilitas dalam pemilu Indonesia. Sigab (Sasana Integrasi dan Advokasi Difabel).

Schur, L., Ameri, M., \& Adya, M. (2017). Disability, voter turnout, and polling place accessibility. Social Science Quarterly, 98(5), 1374-1390.

Seto, B. A. (2015). Aksesibilitas Penyandang Disabilitas dalam Pelayanan Publik Bidang Pendidikan dan Ketenagakerjaan Kota Surakarta.

Virendrakumar, B., Jolley, E., Badu, E., \& Schmidt, E. (2018). Disability inclusive elections in Africa: a systematic review of published and unpublished literature. Disability \& Society, 33(4), 509-538. 